Bulletin-05,01, NEW

$4 / 30 / 01$

$1: 54 \mathrm{PM}$

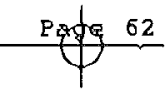

SPECIAL ISSUE

RESTRUCTURING SCHOOLS

\title{
Districts and Schools as a Context for Transformed Counseling Roles
}

Karen Seashore Louis, Lisa M. Jones, and Heidi Barajas

This article afptities three perspectives-structural, culluwral, and practicalto examine issues fuced by district and school administrators as thay attermpt to charige the position and practice of school counsflors to one with a clectr focus on improving academic achieumuent for all studints.

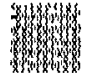

This article prescints a preliminary analysis from six school districts cooperating with partner universities to use school counselors for school improvement. This rescarch is uniquc because references to school counsclors are virtually absent in the burgconing state and local policy initiatives related to schoul improvement. School counsclurs, with backgrounds in child devclopment and experience in school settings, arc wcll positioned to support the efforts of administrators and teachers who are increasingly held accountable for improved performance: by all students. However, both research and policy have focused almost exclusively on curriculum, teaching, and formal school leadership as the manipulable variables that can influence srudent achicvement.

The absence of significant attention to school counseling directed to administuative practice in journals and books is troubling, but it is also evidence of the narrow focus of education. The public thinks of schools as composed of teachers, students, and artministrators. Although statistically accurate, it ignores the reality of current school design, particularly at the secondary school level. A report by Antonucci (1998), using U.S. Department of Education statistics, suggests that states spend betwcen 14 and 30 percent of thcir school-lcvel budgcts on nonteaching personnel, the majority of which supports administrators and student services and instructional sup-

Nate. Thls article was prepared with elupport from the DeWIt Wallace-Reader's Olgest Fund. The ansly. eis does not represent the position of the Fund or of the Universily of Minnesole.

Keren Seeshore Loulg la a professor and Lise M. Jones is a posidoctorel fellow In the College of Education and Human Development, and Heldl Barajas is an asslstant profeseor in the Genaral Callego, University of

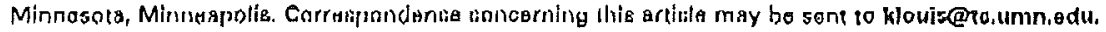

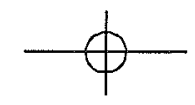


port personnel. Although relevant data are not easily available, it is safe to say that even suburban schools, most of which deal with fewer social probIcms than thcir whan counterparts, employ a large number of licensed profcssionals to support the social and arademic infrastructure of the educational enterprise. Sncial workers, psychologists, school-to-work coordinators, and many other ancillary personncl populate the typical secondary school. The question that has not been addressed is: How effective are these highly trained additional personnel deployed to ruinforce the basic academic goal of the school, ensuring that all childricn will learn?

The school counselor has a nonrationalized role in a rationalized organizational scting. The absence of a clear job description uncouples the counsclor role from school leadership. Fxplaining the counsclor's role in schools requires an examination of school cultures (Handy 1993), which are composed of values, noms, and assumptions about the "right way to do things" (Schejn 1992). It is often assumed that thcrc is a singular culture in a school thal. delermines its acrivities and priorities. Schools, however, also contiun subcultures (Swidler 1986) that form and strengthen during times of inslability and change (Chatman and Jchn 1994). When the environment is calm and supportive, it is easy for teachers, cuunsclory, and parents to see themsclves as a unificd front in support of children. When there is instability and great demand for change, formerly cohesive groups may approach solutions from dramatically different cultural bascy.

Extcrnal environments and pressurcs affect school cutcures but also introduce dynamic:s for change. Rational decision-making processes are affected by a shifting array of problems, potential solutions, and actorsall of which are partially disconnected and unpredictable (March and Olsen 1976). Conserguently, the trajectory of school change is often indirect and only parlially manageable (I.agerweij, Voogt, and Louis 1998).

\section{Method}

The Education Trust', under a grant from the DeWitt Wallace-Reader's Digest Fund (DWRD), developed an agenta in improve counselor education and school counseling practices to realign counsclor roles with improved academic achievement. Six universicy-school district partners were awarded $\$ 450,000$ for a thrcc-year implementation grant from the DWRD called the Transforming School Counseling Initiative (TSCI). The Center for Applied Research and Educational Improvement at the Univcrsity of Minnc:sotat was awarded an eviluation contract to examine the planning and implementation of TSCI and provicle data for other universities and dis-

\footnotetext{
1 Far mare Informatian on The Education Trust and the Transfarming School Coungeling Initlallve, please vist The Educedlon Trust webslea at: http://www.edirust.org/main/achool_coungeling.e日p.
} 
tricts interested in similar reforms. The data used for this study were drawn from that larger evaluation project.

One-week site visits were conducted to the universitics and districts in the late fall and winter of 1999-2000. Two- to three-member teams interviewed district-level counsclor supervisors, practicing counsclors, and principals in at least one elementary, middle, and high school across ear.h site., The purposc of the interviews was to examine how the district context affects the implementation of a spccific rcform effort. We analyzed the casc studles and then conducted cross-silc analysis through summary word tables that documented similarities and diffcrences. Subsequent to the cross-site analysis, cascs were rccxamincd to (a) crisure that the specific attributcs of each case were accorately portrayed and (b) to extract sample quotations to illustrate the conclusions drawn from the word tables.

\section{Findings}

The districts in our sucly ranged from large, urban centers to medium-sized communities. ${ }^{2}$ All included a substantial population of low-income students. In spite of their differences, substantive common themes emerged across the different sctings. Overall the responscs revealed clear patterns that suggest that the redeployment of the school counselor to support student achlevement remains contentious,

Our analysis foctuses on factors in the normal life of schools that present signifirant challenges to changing schnol counselor roles. These include: (a) we ak or noncxistent definitions of the counsclor's job; (b) the role of principals in defining the actual work of counsclors; (c) the predominance of paperwork and adminislation in counselor's claily activitics; and (d) competing organizational criscs and reform agendas that distract district administrators from focusing on counseling.

\section{Ambiguity of Counselor Roles}

Data collected from clistrict and school administrators as well as practicing counsclors reveal dynamic differences in the perspectives of what a counselor can and should do during the collrse of the day, largely due to the absence of a clear job description. The counselor role could become one of advocacy for academic achicvernent. However, in most districts there is no written document that oulines the role of g'tidance counselors, much less one that includes elements of the counsclor as a student achievement advocate. For example, one respondent statcd, "One of the things you asked about... was the status of the discrice's guidance plan.... There isn't any."

2 The schools and districts wera located in Gaorgia, Florida, California, Ohio, and Illinols.
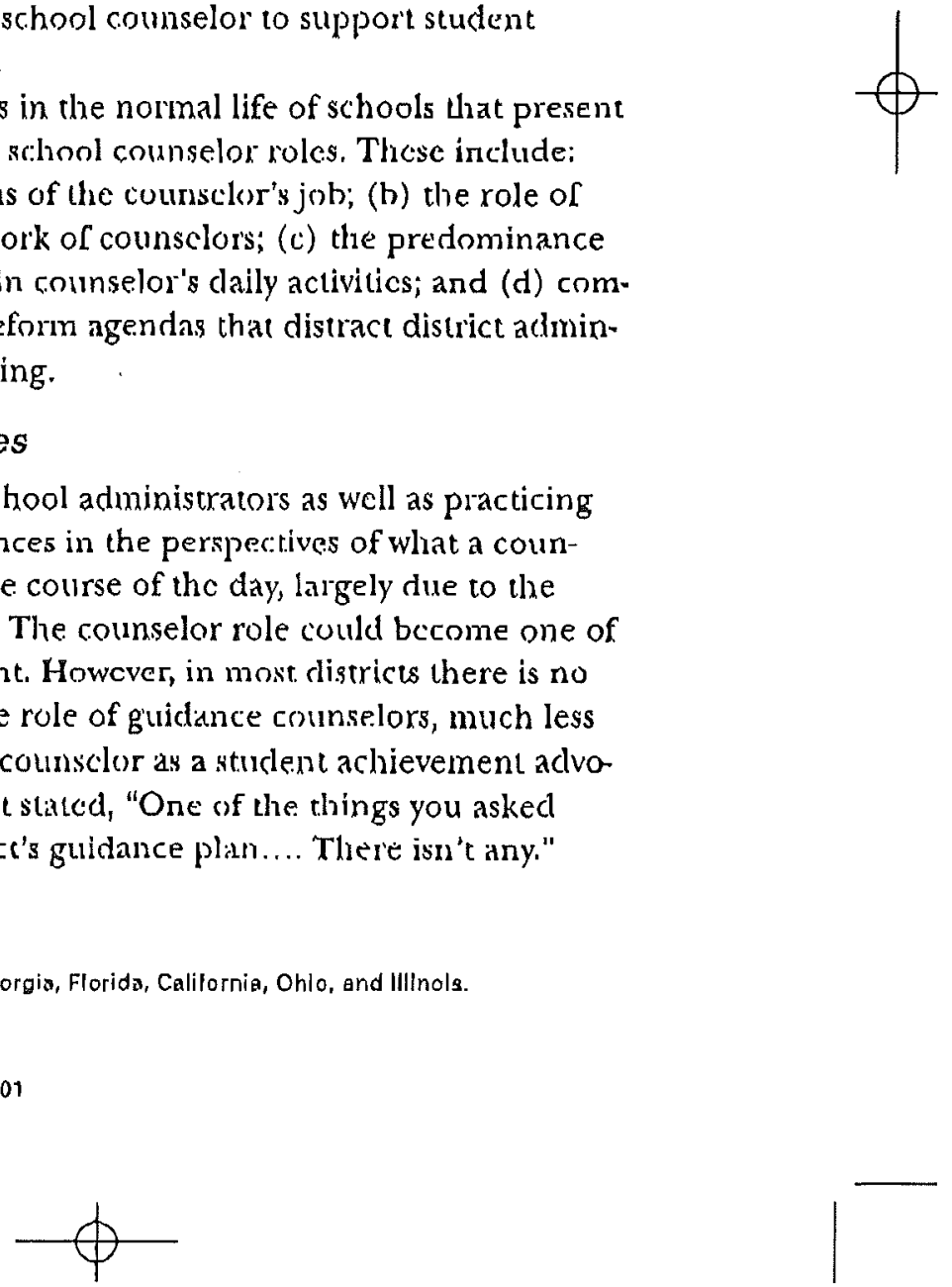
Even when a plan exists, it is often rather vague. One district's mission, for example, states that the counselor bears some responsibilities for academic achicvement. However, the daily operations of the schools encouragc principals to usc counselors in multiple ways that do not necessarily support this mission statement.

A practical consequence of poorly defined roles is that counselors" actual jobs vary enormously from district to district and from school to school. Counselors have little rccoursc to promote a diflerent sct of activities from these that are locally assigned. One administrator said that a problem with the current perception of counsclor roles is that counselors often work alone, isclated from the core academic tcam. This isolated counselor's role is often passive: 'Xou can't ask to be the advocatc. You have to step in and be the advocate... That's going to be a challenge becausc of the people we'xe talking about."

Arluxinistrators in other districts support the pexception of counselors as largely behind-che-scenes actors in unclear roles. There is a strong sensc across districts that many counsclors have not tried to define a professional role based on their training, but have accepted the common definition that they will do whatever is needed in the school to support students and administrators. In some cases this diminishes the potcntial for counselors as partucers in school improvement.

\section{Principals as Interpreters of the Counselor Role}

The districts' andbiguous role definitions force principits to determine what counsclors arcually do. School principals usually have had little exposure to counselors' work, and administralor preparation programs rarely addrcss how principals should use school counsclurs. Thus, each principal must invenc a counscling department and function with the most minimal guidance and expertise-often limited to expcrience gitincd during an internship or in a previous position. Some counselor responclents in this study indicated that anscrive and experienced counselors are often able to educate their principals about and shape principals' definitions or counseling. Howcver, this situation creates uncertainty. Whon a school gets a new principal, the cournsclor's job needs to be renegotiated; the lcss cxperienced the principal, the less likely they are to know how counsclur's might help improve students' academic arhievement, lnstead, counselors become gufcrs who facilitate other school functions and managers who handle unpredictable student crises. Principals assign counsclors tasks on the basis of the perception that because they do not tcach classes, they have the flexibility to perform multiplc clutes. What is valued generally within the school is teaching; if one is not teaching, then onc's job and ume are often viewed as less impontant and morc flexible. One middle schnol counselor delivers paperwork to payroll stating, "I'm the person who is likcly askcd to go [bccausc] I to not. have a class."

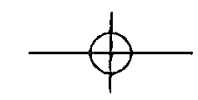


Principals often assign to counselors tasks that lack clear relationslaips to other staff members' job descriptions. For example, one counsclor became the school's truant coordinator. Another principal assigned to the school counselor the role of attendance program coordinator. This counselor provides unexcused absence dara to the state. Neither of these tasks demands the professional preparation required of a school counselor; which typically incluclcs screral ycas's of teaching experience and a master's dcrroc.

\section{Paperwork Dominates Counselors' Work}

Paperwork assigned to counselors is at best looscly relisted to a school's academic goals. State accountability legislation has increased the need for schools to monitor inclividual stuclents and has produced a mountain of test results that must be handled carefilly because they are high-stakes measures of student achievement. Thus, principals justify expanded counselor involvement in testing programs as supporting schools' academic goals;

The proficiency tests drive the role and work of school counselors. We're doing sorting of tests and it's time-consuming for counselors.... Those accivitics are critical for sturlenrs, but is it a counselor who needs to unbox test.s and make sure each reacher gets them?

Principals use counselors for administrative tasks because the schools lack necessary slaff members. Counselors often complain that principals use them as highly paid clerks, herause much of their time is taken up with manual scheduling and review of stuclent records. High schools counselors maintain minimum caseloads of 300 to 400 sturlents. Scheduling and reviewing are undeniahly important but timc-consuming. Administrators tend to view these tasks as critical to student success and a legitimate part of the counselor role, Howcver, one conscquence is that the types of scrvices counselors are trained to provicle for stuclents are actually provicled by others in the school because this type of administrative duty has become their de facto job: "Counselors are viewed primarily as schedulers dning all the paperwork.... [W] have a carcer options specialist... who does more career counseling that we do as counselors.... We don't do career counseling."

The counselor's potential contribution to stuclent achicvement includes his or her ability to go beyond rxacking and recording student rcsults to interpreting sudent. performanre data to develop arademic success strategies.

However, the counselor is not viewed as central to the analysis process. Instead, counsclors continuc to ace as clcrks whilc olhcr proficssionals in the schonl interpret the data.

We have described the atlitudes about the counsclors' roles from the persperrive of the arlministrators. However, it is also important to consider how

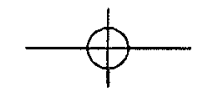


teachers view the counsclors' roles and how counselors believe they should interact with teachers. ${ }^{3}$ We found some agreement among counselors that, in general, teachers do not understand how counselors could aid them in student success. One high school counselor stated, "They don't belicve guidance clocs anything for student achievement. At the high school level, they don't unclerstand anything about counseling...."

\section{Getting the Attention of District Administrators}

The six school districts suldied are large, complicatcd enterprises with many moving parts and many difficult problems to solve, of which improved deployment of counsclors is only one. The standard opcrating procedures and major prioritics of urban and small-city districts often distract from the creation of new counselor roles, not because of a lack of good intentions but because of the pull of other events and distractions. Lack of district leadership is particulally problemaric for counselors because of the variable definition of what counselon do and how important they are: "The leadership acrually has come from the ficld counsclors. That's exactly right; it's actually coming from them with no inter Fcrence from the administration."

The persiscence of tradition rather than policy is compounded by turnover at the district level, which often means that an administrator who finally undersiands the importance of counseling to school improvement is replaced by one who docs nut. In onc district, the director of counseling accepted a job at the state level. Rather than hire a new person to replace her, the supcrintendent give the counscling oversight duties to the dixector of instructional services. Overburdencd with other duties, the administrator provicles only minimal oversight of counselors.

New district administrators often have to be brought along in their understanding of how a counsclor can contribute to school improvement, particulistly if they are focused on raising student tert scores through changes in the curriculum. As a result, counsclor's arc ovcrlooked rather than cxcluded. A counsclor at one site expressed this frustration:

I feel il's disappointing dhat we're not involved at the level we could be. We could be, and we want to be, but we're not.... As far as being on those school improvement committees, I'm sure we have representation [at the district lcvel], but is [it] being uscd as a real active member? I don't think so.

\section{Where Do Counselors' Needs Fit in a Complex Reform Picture?}

Sitc-based management-a kcy clcment of school reform in many of the districts-impedes changing counselor roles. For eximple, in two of the districts

\footnotetext{
3 These commente reflect counselora' perepectived on how they are treated by teachers, and aro
} not besed on Intervlews with leachera. 
sudicd, principals must remain on campus except undcr unusual circumstances and are therefore unable to atrend meetings co learn about the changing comsclor role. In orher districts, poor attendance at meetings to discuss counseling was also the norm because of the perception that "more important" work (for which they had increased responsibility) was going on in the building. Therefore, school principals rarely attend taining that wargets the profussionalization of school commselors. Districr insistence on (or preference for) principals staying in schools rcinforces the use of conunselors as adjunct aclministrators, because their absence from the building is less noticeable.

Discretionary resources arc, of coursc, always a problem for schools, because 85 percent or more of the budget is allocated to relatively inflexible personncl costs. The six districty studicd, like many in the United Statcs, lack the resources for commselors to use information systematically to develop acadcmic programs for students. The allocation of funds across districts dircetly affects whether or not counsclurs are able to participatee in professional devclopment that trains them to use data. Frequently, schools and counselors must absorb the costs of conferences and other training activitics thernsclves.

Equally important, however, is the limited investment that mose districts have been able to make in upgraded rechnology and data systcms. Antiquated databases have nol caught up with recent requircments for tracking sudents. One counselor, for example, reported that it was not possilble to morge student information systcrus that contained grades, attendance, standiardized test results, and health records-except manually. Titrgeting potentially at-risk students was simply not possible. This sjtuation is reflccled elsewhere:

We have a lot of information that our counselors don't know how to access. In a lot of ways it's not activated, it's all bunched together. Because, right now [the dara is] in a great big vat, and you can't pull it out in a form that's usable... Basically, as a counselor in [our district's] schools, we are working on a system that is 1970s, It's an old DOS systcm.

The changing dcmographics of many of the six school districts demand arlditional teaching services for students in need of second language support or spccial education. However, school districts do not allocate resources to involve counsclors in mecting district necds:

[W] necd continual training and inservices. Every day in our school system, there are girls who get pregnant. That's just one problem... We have a huge international contingent, in the past primarily Africion Americans. Now, we're getling lots of Somali kirls, so it's starling over again. Pcople say coumselors need to be

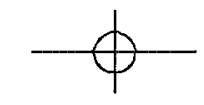


Bulletin-05.01. NEW

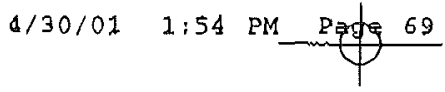

involved in this, but we haven't had the txaining we need to meet the challenge. We always have to teach people more and more.

The way in which districs conduct their daily business deeply affects the deplnyment of school counselor responsibilities. Administrator turnover creates a policy vacuum that deprives counsclors of a centralized role in school improvement efforts. Counselors get sucked into the black hole of "other dutics as assigned" because of limited central support. Districts lack rcsources, such as sophisticated databases that enable counselors to perform their duties. Moreover, changes in cducation funding formulas force districts to set fiscal prioritios that do not necessarily include professional development funds for counsclors to retrain themselves to adapt to distrists' changing demographics and social tensions.

\section{Competing State-Level Reform Agendas}

On the national level, the trend is toward systemic reform in which state policymakers take more control over school impiovement efforts. School districts must target their fiscal and human resourccs to satisfy state requirements for documentation. School counsclor's still attend to basic clerical tasks associated with assessment rather than develop plans to encourage and assist sudents in academic achievement. Therefore, counselors are largcly ignored in the state accountability reforms. One respondent suggested that it is crucial that counselors become playcrs in student achievement if state goals are to be met: "For 20 to 25 years, counsclor's have had the skills and training. Now the focus is on accountability-defined as how students pexform. If wc don't all focus on arhievement, then the urban schools will fail."

At the sume time, however, educators are reluctant to discuss the counselor's role in accountability because they oftcn perceive counseling reform and increased accountability as competing rather than complementary goals: "We can't go in to talk about reforming lyc counselor role given the criscs being faced by the schonl community." Dcmands for improved achicvement on standardized tcsts create tensjons withoul providing additional resources because counsclors play a clcrical role in accountability.

In addition to increasing counsclor's' workloads, assessment appears to interfere with other activities that counsclors believe could benefit the school community:

Five stuchents died in the school system (last year). Four from violent deaths and one death rcsulted from a student being hit by a schnol hus. We need school counselors to be involved in this. Even if we were doing proficiency tests, we conld ardicss thesc crises. But we get bogged down with other things, like assessment. I believe in assessment but right now, it is too heavy a load for the guidance counsclors. 
- Eulletin-05.01.NEW

$4 / 30 / 01$

1:54 PM

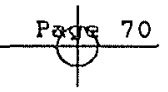

At anocher site, the narrow focus on assessment detracts from the other indicators of academic achicvement. For example, in one state, consistent school altendance is not considered at all, wherens in another state, counsclors are responsible for reporting all state attendance data. Counselors' clforts to bccome involved in career planning and cducation may be sidctracked by cflorts to improve sperific test scores. All of the districts have a local prioricy of enabling stuclents ro develop reasonatle postsecondary plans-but student success after high school is not considered in any of the states' accountability plans.

\section{Moving Toward Success: Stories of Change}

The analysis suggests that the use of counselors as extensions of the school administrator's functions predominates. Despite the concextual elements that discount the role of the school counselor in school rcform, sices have developed creative ways to rcdeploy counselors. These sitcs modified the rccommendations of The Education Trust to fit thcir local context. For example, one site bypassed the bureaucratic, cumbersnme district office and clirected its efforts at a "family" of focder schools in rerested in incegrating counselors in school improvement. School counselors now deliver carccr modules to stuclents in classes, Another site cstablished a counselor-of-the day responsible for daily front-office duties, including discipline, parent concerns, and social scrvices. The remaining counselors work directly with teachers, parent centers, and student groups on efforts to improve student ar.hievement. At a third site, the univcrsity-initiated professional devclupment program encouraged the dcsign of formal protocols to assess counsclor job perfomance. Student outcome measures established by the Ancrican School Counseling Assoriation are now intcgrated into the school counsclors' annual performance review. Finally, one sitc aligned counselors' jobs with federally funcled school improvement initiatives. These are focused on the connection berween counseling and acadcrnic preparation through such programs as Gear Up, Title VI, and the National Science Foundation Urban Systcmic Initiative Grant.

\section{Implications}

The above discourse leads to several conclusions that have implications for changing the roles that counselors play in the lives of schools and students. Each of thesc conclusions stems fiom the hasic pronisc outlined at the beginning of the article that the role of school counselors remains an anomaly in torlay's erlucational system. Though thcy are members of a professional group that is regulated, licensed, and well respected in contemporary society, schnol counselors occupy an indistinct area in the educational bureaucracy. 
Although school counsclors are acknowledged as experts, their particulax expertise is poorly understood and ill defined inside their organizational sctings. This finding is uniform across the districts and schools that were examined in this study. This article offers several cxamples of how school counselors' rolcs fall into an administrative gray arta. Until districts and schools pay closer atrention to the factors detracting from effective integration of counselors into school improvement efforts, the counsclor will romain an underurilized resource in raising student achievement.

\section{District and School Context Matters}

Any attompt to change the role of school counselors will occur within a district and school context that presents specific challenges. Some of these challenges include the varying interpretations of the counselor's role at the school level; district operations that shift priorities away from the counselor; and high-priority reform agendas that redirect resources to arccountability. Although the constraints that we have outhined are common across seltings, the specific opportunities to address the barricrs vary widely. Changing the rolc at the ground level can progress depending on the ability of administrators to scan their local seltings and align spectific issues with school counseling.

\section{Counselor Roles Need More Definition Within Districts}

Our analysis suggests that efforts to reduce the invisibility of coumselor roles are circumscribed by the largely undefined rolc of counselors in the district bureancracy. A clear role description at he district lovel could gaide and encomarge principals to legitimize the role of the schoul counselor as central to ararlemic achievement. The ability of individual counsclors to attach themsclvcs to a school's academic agenda is not legitimized by district policy and chus depends on the particular charactcristirs-and immediate crisesof the schools in which thcy work. Under ideal circumstances, an influcntial discrict administrator can help to promote the agenda, but the organizational rurbulence in many district offices means that yesterday's critical ally may be gonc comorrow, lcaving a thin paper trail of decisions and agr'ccment.

\section{Principals Necessary for Change}

Regardless of district policies and initiatives, principals retain the core responsibility of redistributing the workload and making decisions about immediate school prioritics. The university and district partners who have allempled to involve principals in redeploying counselors have concluded that principals who understand the potential of cuunsclors are rare. Principals can have a tremendous influence if thcy work to reduce the isolation of counsclors within the schools and if they imagine how a unique school counsclor rolc could hclp them in their own work. Principals who have 
become involved after the fact have bcen largely inelfeclive because they did not have a vision for realizing school counselor potential and because of the persistent tendency of districts to ignore principals' professional development needs. Bridges must he built between comneling and teaching professionals. However, for this to occur, principals must understand and advocate for this fundancrutal chainge.

\section{Conclusions}

We draw three substancive conclusions from this study. First, district-level administrators could realign the schonl counselor role with improved student achievement, which is central to school refom efforts. Second, absent systemic district changc, the principal plays a crucial role in redirecting school counsc:Iors fiom clerical tasks to thesc dutics that capitalize on school counselor training to crabance student academic performance. Finally, principals may explore sclooul counsclor craining and evaluate how to usc counsclors' skills fully within the context of accountability pressures. With carcful attention to these findings, school counselors can serve as an additional profcssional rcsource for school administrators, con tribute tangibly to the goals of the larger school community, and simultaneously enhance their own job satisfaction.

\section{References}

Antonucci, M. 1998. One yard beloun Sacramento, Calif: The Education Intelligence Agency.

Chaman, J., and K. Jehn. 1994. Asscssing the relationship between industry characteristics and organizational culturcs: How dillerent can you be? Academy of Management Review 37 (3): 522-53.

Handy, C. 1998. Understanding organizations. Oxford, England: Oxford University Pre.s.

Lagerweij, N., J. Voogt, and K. S. Louis. 1998. School devclopment and organizational leaming: Toward an integrative theory. In Organizational laaming in schools, cditcd by K. Leithwood and K. S. Louis. Lisse, The Netherlands: Swcts and Zeillinges:

March, J. G, and Olscn, J. 1976. Ambiguity and organizutional choice. Bergen, Norway: Universitets[orlaget.

Schein, E. 1992. Organizational callecre and leadership. 2nd ed. San Francisco: Jossey-Bass.

Swidler, A. 1986. Culure in action: Symbols and strategies. American Sociological Revieu 51 (2): 273-86.

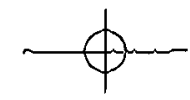

